\title{
An alternative method that reduces homologous blood use In open heart surgery; cell saver
}

\author{
Melike Elif Teker ${ }^{1,2^{*}}$ and I. Bayer Cınar ${ }^{2}$
}

*Correspondence: melikelif_teker@hotmail.com

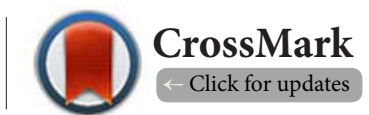

'Biruni Unıversity Hospital, Department of Cardiovascular Surgery, İstanbul, Turkey.

${ }^{2}$ Fatih Medical Park Hospital, Department of Cardiovascular Surgery, İstanbul, Turkey.

\begin{abstract}
Objective: Today the use of autologous blood or more effective use of the patient's own bloodespecially during heart surgeries which requires a significant amount of blood transfusion are being investigated since the use of homologous blood can lead to undesired results. In this study, we aimed to comparatively evaluate the effects of the cell saver device on the drainage, need for blood and blood products, postoperative infection complications and length of intensive care unit stay between patients in whom the device was and was not used.

Material and Method: 170 patients who underwent open heart surgery between January 2014 and December 2015 were studied. 85 of these patients constituted the control group (group 1) and 85 were the study group (group 2). The two groups were compared in terms of parameters such as the amount of blood lost postoperatively (drainage) through mediastinal drain, need for blood and blood products, length of intensive care unit stay and postoperative infections.

Results: For Group 1 and 2, mediastinal drainage amounts were $581 \pm 363 \mathrm{ml}$ and $323 \pm 158 \mathrm{ml}$ respectively, need for blood and blood products were $2.28 \mathrm{u}$ and $1.03 \mathrm{u}$ respectively, and lengths of intensive care unit stay were $28.9 \pm 1.5 \mathrm{hr}$ versus $29.3 \pm 9.1 \mathrm{hr}$ respectively.

Conclusion: Since the patient's own blood is used, the cell saver method involves no risk of homologous blood transfusion-related infections or development of any allergic reactions or complications. Moreover, since it can also be used in emergency surgeries, it provides comfort and confidence to the surgeon in patients in critical condition and in those with rare blood groups.
\end{abstract}

Keywords: Blood transfusion, heart surgery, cell saver, homologous blood, postoperative infection

\section{Introduction}

There is a need for large amounts of homologous blood in heart surgery because of large amounts of bleeding [1]. Cardiopulmonary bypass or other cardiac surgeries account for about $10 \%$ of all blood product usage [2]. Today, because of the harmful effects ofhomologous blood use such as febrile reactions or bacterial infections, the use of autologous blood or more effective use of the patient's own blood especially during heart surgeries are being investigated [3].

Autotransfusion has reduced the homologous blood use from an average of 7-8 units to 1-2 units [4]. Moreover, autotransfusion is safe in surgical interventions in patients with rare blood groups, those who require emergency surgery and those with hypersensitivity [4].
In this study, we aimed to comparatively evaluate the effects of cell saver device on the drainage, need for blood and blood products, postoperative infections, length of intensive care unit stay and discharge time between patients in whom the device was and was not used.

\section{Material and method}

170 patients who underwent open heart surgery between January 2014 and December 2015 were studied. 85 of these patients constituted the control group (group 1) and 85 were the study group (group 2) Following the median sternotomy, patients were anticoagulated with heparin sodium to attain an ACT (activated clotting time) of 480 seconds, routine aortic cannulation and right atrial two stage venous cannulation 
Teker et al. Cardiovascular System 2017,

was performed, then the pump was initiated. Membrane oxygenator was used in all patients, and the operation was performed under moderate hypothermia induced by warm and cold blood cardioplegia.

The 'cell saver' device was used in the study group. The remaining blood from the extracorporeal circulation, was aspirated into the device, centrifuged, washed with saline, and administered to the patients as erythrocyte suspension.

The patients were compared in terms of age, gender, diabetes mellitus (DM), hypertension (HT), cross-clamp (CC) time and duration of cardiopulmonary bypass (CPB).

Additionally, hematocrit, platelets, prothrombin time, fibrinogen, RBCs and WBCs were measured in blood samples collected at two times, preoperatively and on the postoperative first day. Activated prothrombin time (APTT) and ACT were measured only on the day of surgery.

The two groups were compared in terms of the amounts of blood transfused (from donors, banks and total), total drainages, blood amounts collected into the cell saver device and hematocrit values, length of intensive care unit stay, revision due to bleeding, and postoperative infectious and transfusion-related complications to find out if there are statistically significant differences.

\section{Statistical evaluation}

The statistical evaluation of the data was performed using SPSS version 11.5 software package. The data were expressed as mean \pm standard deviation. The association of transferred amounts of blood with mortality and bleeding was investigated using Mann-Whitney's U-test. Significance of the difference between the preoperative and postoperative measurements was evaluated using Wilcoxon's test. Values $p<0.05$ were considered statistically significant.

\section{Results}

The control group included 62 male and 23 female patients with amean age of 62.5 years while the study group included 61 male and 24 female patients with a mean age of 58.9 years (Table 1).

No significant differences were found between the groups in terms of the demographic characteristics including age,

Table 1. Demographic and Clinical Data of Patients.

\begin{tabular}{lllll}
\hline & \multicolumn{2}{l}{ Control $(\mathrm{N}=85)$} & \multicolumn{2}{l}{ Study $(\mathrm{N}=85)$} \\
\hline & Number & Percent & Number & Percent \\
\hline Mean age (years) & 62.5 & -- & 58.9 & -- \\
Male & 62 & 72.9 & 61 & 71.8 \\
Hypertension & 43 & 51.4 & 38 & 45.7 \\
Diabetes & 30 & 34.2 & 26 & 31.4 \\
Smoke & 43 & 51.4 & 38 & 45.7 \\
Chronic obstructive & 5 & 17.1 & 5 & 17.1 \\
pulmonary disease & & & & \\
\hline
\end{tabular}

sex, DM and HT, and cross-clamp times.

The mean duration of cardiopulmonary bypass was $69 \pm 15$ and $63 \pm 05$ minutes in the control and study groups, respectively. The mean amounts of blood transfused to the control and study groups were $2.28 \mathrm{U}(0.8 \mathrm{U}$ from donors and $1.48 \mathrm{U}$ from banks) and $1.03 \mathrm{U}$ ( $0.6 \mathrm{U}$ from donors and $0.43 \mathrm{U}$ from banks) (Table 2). The amount of blood transfused was significantlylower in the study group compared to control $(p<0.05)$.

Drainage amounts were $581 \pm 363 \mathrm{ml}$ and $323 \pm 158 \mathrm{ml}$ in

Table 2. Data Postoperative.

\begin{tabular}{|c|c|c|c|}
\hline & Control & Study & P-value \\
\hline drainage (milliliter) & $581 \pm 363 \mathrm{ml}$ & $323 \pm 158$ & $\mathrm{p}<0.05$ \\
\hline $\begin{array}{l}\text { Autotransfusion } \\
\text { (milliliter) }\end{array}$ & $0,8 \pm 0.2 \ddot{U}$ & $0,6 \pm 0.03 \ddot{U}$ & $\mathrm{p}<0.05$ \\
\hline Blood bank (unit) & $1,48 \pm 0.7 \ddot{U}$ & $0.43 \pm 0.1 \ddot{\mathrm{U}}$ & $\mathrm{p}<0.05$ \\
\hline Fresh frozen plasma & $1.2 \pm 0.3 \ddot{U}$ & $1.1 \pm 0.28 \ddot{\mathrm{U}}$ & normal \\
\hline Ischemia time (minute) & $38.5 \pm 15.2$ & $39.7 \pm 14.2$ & normal \\
\hline $\begin{array}{l}\text { The Residence Time in } \\
\text { the ventilator (hour) }\end{array}$ & 23.5 & 22,8 & normal \\
\hline ICU stay & $28.9 \pm 1.5$ hour & $29.3 \pm 9.1$ hour & normal \\
\hline Revision & 0 & 0 & -- \\
\hline Death & 0 & 0 & -- \\
\hline
\end{tabular}

the control and study groups, respectively. In the study group, almost all of the blood collected into the cell saver was returned to the patients. The fresh frozen plasma transfusions were $1.2 \pm 0.5 \mathrm{U}$ and $1.1 \pm 0.2 \mathrm{U}$ and the lengths of intensive care unit stay $28.9 \pm 1.5$ hours and $31.3 \pm 9.1$ hours in the control and study groups, respectively, with no significant difference.

No statistically significant differences were found between the two groups in terms of platelets, prothrombin times, preoperative hematocrit levels, APTT and fibrinogen values.

In terms of RBCs, the difference between the values of the two groups on the postoperative $0^{\text {th }}$ day was statistically significant (the mean values were $2.583 .000 / \mathrm{mm} 3$ and $1.835 .000 / \mathrm{mm} 3$ in the study and control groups, respectively; $\mathrm{p}<0.05$ ). WBCs increased during the postoperative period in both groups, but the difference was not significant (Table 3). No mortality or infection was observed.

\section{Discussion}

The amount of blood transfused was lower in the group in which the cell saver was used, and the difference was statistically significant $(p<0.05)$. The amount of fresh frozen plasma given was not significantly different between the two groups No statistically significant differences were found between the two groups in terms of platelets, prothrom bin times, preoperative hematocrit levels, APTT and fibrinogen values. In terms of RBCs, the difference between the values of the two groups on the day of surgery was statistically significant.

Since the patient's own blood is used, the cell saver 
Teker et al. Cardiovascular System 2017,

http://www.hoajonline.com/journals/pdf/2052-4358-5-1.pdf

doi: $10.7243 / 2052-4358-5-1$

Table 3. Preoperative and postoperative hematological parameters.

\begin{tabular}{|c|c|c|c|c|c|c|}
\hline & \multicolumn{2}{|c|}{ Group1 (control) } & \multicolumn{2}{|l|}{ Group2 (study) } & \multicolumn{2}{|l|}{ Percent } \\
\hline & Before surgery & Postoperative & Before surgery & Postoperative & Before surgery & Postoperative \\
\hline hematocrit & $31.6 \pm 3.7$ & $26.8 \pm 3.0$ & $32.0 \pm 3.87$ & $29.8 \pm 3.0$ & normal & normal \\
\hline platelets $\left(\mathrm{x} 10^{-3} / \mu \mathrm{l}\right)$ & $167 \pm 38.7$ & $166 \pm 41.3$ & $179 \pm 46.5$ & $171 \pm 48.6$ & normal & normal \\
\hline aPTT (sn) & $36.5 \pm 0.5$ & -- & $38.3 \pm 0.5$ & -- & normal & normal \\
\hline $\begin{array}{l}\text { The number of white cells } \\
\left(\mathrm{x} 10^{-3} / \mu \mathrm{l}\right)\end{array}$ & $12.5 \pm 1.7$ & $13.4 \pm 2.4$ & $13.1 \pm 3.08$ & $12.9 \pm 9.0$ & normal & normal \\
\hline Erythrocyte $10^{6} / \mathrm{ml}$ & $4.42 \pm 0.5$ & $2.583 \pm 0.5$ & $4.28 \pm 0.5$ & $1.835 \pm 0.5$ & -- & $\mathrm{p}<0.05$ \\
\hline
\end{tabular}

method involves no risk of homologous blood transfusionrelated infections or development of any allergic reactions or complications.

Blood transfusion is still common in cardiac surgery. In the US, $16-20 \%$ of all blood transfusions have been used in coronary bypass patients [5]. Massive homologous blood transfusion in heart surgery can cause harmful effects such as hemolytic effects (intra- or extravascular hemolysis, high antibody titer), febrile reactions, bacterial reactions, and disease transmission $[6,7]$. Moreover, transfusion of homologous blood and blood products increases postoperative infectious complications such as sepsis [8]. The possibility of such complications should be considered when transfusing homologous blood. Therefore, unnecessary use of blood and blood products should be avoided. Additionally, a study demonstrated that based on the short- and long-term results of patients who underwent cardiac surgery, blood transfusion increases mortality and morbidity $[9, \mathbf{1 0}]$.

Various methods are used to reduce the homologous blood use during cardiac surgery [11]. The common purpose of these methods is to increase the preoperative erythrocyte mass, to not allow postoperative anemia and to reduce the erythrocyte loss $[12,13]$. The procedure of returning blood collected from the patients was firstly described by Blundell in 1818. The patient's own blood can be used by (i) preoperative collection of blood from the patient, and storage after subjecting to certain processes; (ii) phlebotomy and volume replacement during early surgery, (iii) returning to the patient through autotransfusion (cell saver) during the surgery [14].

The Cell Saver device was developed due to the increasing demand to avoid blood transfusion and the desire to reduce blood loss during and after the operation $[15,16]$. A meta-analysis demonstrated that cell saver reduces allogeneic blood transfusion by $39 \%$ and the needfor blood collection by $23 \%$ [17]. Cell saver method has many important advantages over donor blood. The most important one is that the transfused blood is the patient's own blood. So, there is no risk of development of an infection or allergic reaction or complication associated with allogeneic blood transfusion. The other advantages are that the blood that is made reusable by processing is fresh, can be used not only in scheduled operations but also in emergency surgeries, and it is also possible to use this blood having a high oxygen-carrying capacity, few active particles and low levels of cytokine and active complements and of which the lipid particles have been eliminated, in patients in critical condition and in those with rare blood groups [18].

The study of Chenoworth et al. demonstrated that some vasoactive elements such as complements (C3, Cs) are continuously produced by the cardiotomy suction system thereby increasing their blood levels $[19,20]$. These high levels of complements and other vasoactive elements (thromboxane etc.) are removed from the blood through cell washing system $[19,20]$. This is considered to be an advantage of cell saver method. Ozbaran et al., [7] reported that the use of cell savers in coronary bypass surgeries significantly reduces homologblood use, does not cause a significant reduction in blood proteins, platelet counts and the other coagulation factors, therefore, it does not prolong ACT and APTT.

Some studies demonstrated that cell saver devices increase hemoglobin concentrations and reduce intraoperative blood loss in cardiac surgery $[\mathbf{2 1}, \mathbf{2 2}]$. Postoperative bleeding can cause renal and pulmonary complications, arrhythmia and increased mortality in patients who underwent heart surgery [22]. The use of cell saver, postoperative collection of chest tube drainage and antifibrinolytics reduce blood loss and the need for transfusion [23].

Postoperative bleeding and reoperation also increase the need forperioperative blood. Moreover, it was found to cause a mild reduction in hematocrit levels during the postoperative period [24]. Many authors reported that cell saver reduces not only the morbidity but also the mortality rates during the postoperative period [25].

Cell saver device is used to protect patients from infections in open heart surgery [26]. Considering that homologous blood transfusion during open heart surgery increases the risk of infection by $1 \%$ for 1 unit, $20 \%$ for $2-4$ units, $50 \%$ for $5-8$ units and $69 \%$ for $>9$ units of transfusion [27], the cell saver method that uses the patient's own blood protects patients from infections [26].

Although the cost of this technique is still a question of debate and seems to increase the cost of the operation, it was reported that cell saver reduces the total cost in $500 \mathrm{ml}$ and higher transfusions [28]. On the other hand, autologous 
Teker et al. Cardiovascular System 2017,

http://www.hoajonline.com/journals/pdf/2052-4358-5-1.pdf

doi: $10.7243 / 2052-4358-5-1$

blood transfusion is preferred to avoid transfusion-transmitted blood diseases [29].

\section{Competing interests}

The authors declare that they have no competing interests.

Authors' contributions

\begin{tabular}{|l|c|c|}
\hline Authors' contributions & MET & IBC \\
\hline Research concept and design & $\checkmark$ & -- \\
\hline Collection and/or assembly of data & $\checkmark$ & $\checkmark$ \\
\hline Data analysis and interpretation & $\checkmark$ & -- \\
\hline Writing the article & $\checkmark$ & -- \\
\hline Critical revision of the article & $\checkmark$ & -- \\
\hline Final approval of article & $\checkmark$ & -- \\
\hline Statistical analysis & -- & $\checkmark$ \\
\hline
\end{tabular}

Acknowledgement

I thank everyone who contributed.

\section{Publication history}

Editor: Chunyu Zeng, Third Military Medical University, China. Received: 24-Jan-2017 Final Revised: 22-Mar-2017

Accepted: 03-Apr-2017 Published: 28-Apr-2017

\section{References}

1. Engoren MC, Habib RH, Zacharias A, Schwann TA, Riordan CJ and Durham SJ. Effect of blood transfusion on long-term survival after cardiac operation. Ann Thorac Surg. 2002; 74:1180-6. | Article | PubMed

2. Graves EJ. National hospital discharge survey: annual summary, 1991. Vital Health Stat 13. 1993; 1-62. I Pdf | PubMed

3. Ovrum E, Holen EA, Abdelnoor M and Oystese R. Conventional blood conservation techniques in $\mathbf{5 0 0}$ consecutive coronary artery bypass operations. Ann Thorac Surg. 1991; 52:500-5. | Article | PubMed

4. Korukçu $A$, Karabulut $H$ and Tosun $R$, et al. Effect of Remaining Venous Reservoir Blood Administration on Transfusion in Open Heart Surgery Türk Kardiyol Dern Arş. 1996; 24:540-4.

5. Basran S, Frumento RJ, Cohen A, Lee S, Du Y, Nishanian E, Kaplan HS, Stafford-Smith $M$ and Bennett-Guerrero $E$. The association between duration of storage of transfused red blood cells and morbidity and mortality after reoperative cardiac surgery. Anesth Analg. 2006; 103:1520. | Article | PubMed

6. National blood centers and transfusion tibbi course booklet. 1997; 197.

7. Kochamba GS, Pfeffer TA, Sintek CF and Khonsari S. Intraoperative autotransfusion reduces blood loss after cardiopulmonary bypass. Ann Thorac Surg. 1996; 61:900-3. | Article | PubMed

8. Ekim $\mathrm{H}$, Kutay $\mathrm{V}$ and Başel $\mathrm{H}$ et al. Revision Operations For Hemorrhage After Open Heart Surgery Van Tip Dergisi 2004; 11:119-23.

9. Koch CG, Li L, Duncan Al, Mihaljevic T, Cosgrove DM, Loop FD, Starr NJ and Blackstone $\mathrm{EH}$. Morbidity and mortality risk associated with red blood cell and blood-component transfusion in isolated coronary artery bypass grafting. Crit Care Med. 2006; 34:1608-16. | Article | PubMed

10. Reeves BC and Murphy GJ. Increased mortality, morbidity, and cost associated with red blood cell transfusion after cardiac surgery. Curr Opin Cardiol. 2008; 23:607-12. | Article | PubMed

11. Reyes G, Prieto M, Alvarez P, Orts M, Bustamante J, Santos G, Sarraj A and Planas A. Cell saving systems do not reduce the need of transfusion in low-risk patients undergoing cardiac surgery. Interact Cardiovasc Thorac Surg. 2011; 12:189-93. | Article | PubMed

12. Giordano GF, Sr., Giordano GF, Jr., Rivers SL, Chung GK, Mammana RB, Marco JD, Raczkowski AR, Sabbagh A, Sanderson RG and Strug BS. Determinants of homologous blood usage utilizing autologous platelet- rich plasma in cardiac operations. Ann Thorac Surg. 1989; 47:897-902. I Article | PubMed

13. Harker LA, Malpass TW, Branson HE, Hessel EA, 2nd and Slichter $\mathrm{SJ}$. Mechanism of abnormal bleeding in patients undergoing cardiopulmonary bypass: acquired transient platelet dysfunction associated with selective alpha-granule release. Blood. 1980; 56:824-34. | Article | PubMed

14. Taylor KM. Blood conservation during cardio pulmonary bypassautologous transfusion, Cell saving and haemo filtration. In: Cardiopulmonary bypass. London: Chapmanand Hall; 1986; 289-07.

15. McGill N, O'Shaughnessy D, Pickering R, Herbertson M and Gill R. Mechanical methods of reducing blood transfusion in cardiac surgery: randomised controlled trial. BMJ. 2002; 324:1299. | Article | PubMed Abstract | PubMed FullText

16. Diprose P, Herbertson MJ and O'Shaughnessy DO et al. Reducing allogeneic transfusion in cardiac surgery: a randomized double- blind placebo controlled trial of antifibrinolytic therapies used in addition to intra-operative CS. Br J Anaesth. 2005; 94:271-8.

17. Carless PA, Henry DA, Moxey AJ, O'Connell D L, Brown T and Fergusson DA. Cell salvage for minimising perioperative allogeneic blood transfusion. Cochrane Database Syst Rev. 2006; CD001888. | Article | PubMed

18. Jewell $A E$, Akowuah EF and Suvarna SK et al. Prospective randomised comparison of cardio tomysuction and cell saver forrecy clings hed blood during cardiac surgery. Eur J Cardiothorac Surg. 2003; 23:633-6.

19. Tennenberg SD, Clardy SW and Bailey WW et al Complement activation and lung permeability during cardio pulmonary bypass. AnnThorac Surg. 1990; 50:597-01.| Article

20. Chenoweth DE, Cooper SW, Hugli TE, Stewart RW, Blackstone EH and Kirklin JW. Complement activation during cardiopulmonary bypass: evidence for generation of $\mathrm{C} 3 \mathrm{a}$ and $\mathrm{C} 5 \mathrm{a}$ anaphylatoxins. N Engl J Med. 1981; 304:497-503. | Article | PubMed

21. Wang G, Bainbridge $D$, Martin J and Cheng D. The efficacy of an intraoperative cell saver during cardiac surgery: a meta-analysis of randomized trials. Anesth Analg. 2009; 109:320-30. | Article I PubMed

22. Hall TS, Brevetti GR, Skoultchi AJ, Sines JC, Gregory P and Spotnitz AJ. Re-exploration for hemorrhage following open heart surgery differentiation on the causes of bleeding and the impact on patient outcomes. Ann Thorac Cardiovasc Surg. 2001; 7:352-7. | Pdf | PubMed

23. Aşkar FZ, Çetin HY and Önal A. Anesthesia in aortic surgery. İstanbul: Yüce Yayıncılık. 2003. 527-64.

24. Hannan EL, Samadashvili Z and Lahey SJ et al. Predictors of postoperative hematocrit and association of hematocrit with adverse outcomes for coronaryartery bypass graftsurgery patients with cardio pulmonary bypass. J CardSurg. 2010; 25:638-46.

25. Jakobsen $C J$, Ryhammer PK and Tang $M$ et al. Transfusion of blood duringcardiacsurgery is associated with higher long-termmortality in low-risk patients. Eur J Cardiothorac Surg. 2012; 42:114-20.

26. Carless PA, Henry DA, Moxey AJ, O'Connell D L, Brown T and Fergusson $D A$. Cell salvage for minimising perioperative allogeneic blood transfusion. Cochrane Database Syst Rev. 2006; CD001888. | Article | PubMed

27. Dinççağ A.Preventions Against Microorganisms in Surgery. ANKEM Derg. 2004; 18:222-8.

28. Chanda A, Smith DR and Nanda A. Autotransfusion by cell saver technique in surgery of lumbar and thoracic spinal fusion with instrumentation. J Neurosurg. 2002; 96:298-303. | PubMed

29. Desmond M. Peroperative cell salvage. Transfus ClinBiol. 2007; 14:530-2.

\section{Citation:}

Teker ME and Cinar İB. An alternative method that reduces homologous blood use In open heart surgery; cell saver. Cardio Vasc Syst. 2017; 5:1.

http://dx.doi.org/10.7243/2052-4358-5-1 